\title{
First Term Support for International Graduate Students Attending Small Colleges and Universities
}

\author{
Mary Jo Shane \\ Loredana Carson \\ Gloria Macri \\ California Lutheran University, USA
}

\begin{abstract}
The recruitment and retention of international students in academic institutions in the United States has become more complicated and more competitive than ever before given the current political climate and governmental policies. This article discusses some of the specific challenges international students face and what a small- to medium-sized private university has put in place to attract these students and to better prepare them for graduate level management courses starting their first term. This example introduces an 11-week foundations course along with additional resources designed to provide knowledge, instruction, and practice in skills and behaviors crucial for academic success within the United States.
\end{abstract}

Keywords: foundations course, graduate students, international students, student success

\section{INTRODUCTION}

This study discusses a first-term foundations course for international graduate students, Advanced Academic \& Professional Practices (Foundations 500), along with additional resources that can be used to both attract prospective international graduate students and help increase persistence. Such a course shows the level of support students can expect from a given institution, as well as enables these students to more easily navigate what is, for many, an unfamiliar academic environment. Besides the costs associated with the development and instruction of this type of specialized course that is geared specifically to mitigate the challenges these students 
face, the resources discussed herein have been implemented with little to no extra funding and, in some cases, through the efforts of campus and community volunteers (i.e., volunteers who work with students on improving their spoken English) something that can be important when it comes to adherence to budgetary restrictions experienced by many small- to mid-sized colleges and universities. Developing resources that require little to no extra funding can also help provide a level of sustained support to students regardless of any budgetary restrictions forecasted for the future.

\section{LITERATURE REVIEW}

\section{Benefits of International Students}

The benefits that international students bring to our academic institutions have been discussed in many previous studies (e.g., Montgomery, 2017; Ryan, 2005b; Sawir, 2013). According to Sawir's (2013) qualitative study, apart from economic benefits, international students offer two additional contributions: They help broaden cultural horizons and are a cultural resource for teaching and learning. By providing opportunities for international students to share knowledge about their home countries and cultures with other students (e.g., business ethics and etiquette), an appreciation and understanding of how to work more effectively in other countries and in a global work environment can be enhanced (Coates \& Dickinson, 2012; Ryan \& Carroll, 2005; Wu et al., 2015). International students also bring different beliefs, experiences, and perspectives to our institutions and classroom discussions (Korobova \& Starobin, 2015), which can help develop critical and creative thinking, as well as cross-cultural communication skills for both domestic and international students alike (Ryan \& Hellmundt, 2005).

\section{International Student Challenges}

While institutions are able to garner numerous benefits from admitting international students, research indicates that international students have different challenges, beliefs, and needs from domestic students (e.g., Sun et al., 2016; Yan \& Sendall, 2016). Many of the challenges that affect international students are discussed below.

\section{Attributes for Success}

As Ryan and Carroll (2005) noted, "International students arrive with a set of skills and experiences which have equipped them in the past to be successful but which may not be fully useful in their new setting" (p. 5). Assumptions about appropriate classroom behavior, how they should interact with instructors and peers, what and how to study, when to talk and when to remain silent, and rules of academia may no longer be familiar (Ryan, 2005b; Shapiro et al., 2014). Fadil (2010) further explained that the attributes for success that are valued academically as well as professionally in the United States, such as competitiveness and self-motivation, are new to many international students. Students may experience what these and other 
authors refer to as "academic shock" (Coates \& Dickinson, 2012; Ryan \& Carroll, 2005; Shapiro et al., 2014). This is the type of shock "students experience when their confidence plummets, they question their previous self-evaluation as competent learners, and they may even lose their knowledge about how to learn and succeed" (Ryan \& Carroll, 2005, p. 7).

\section{Intellectual Ownership and Academic Integrity}

One rule in particular that concerns most academic institutions and instructors alike has to do with concepts of intellectual ownership and academic dishonesty. Unfortunately, many believe that international students cheat and violate policies of academic integrity simply to "get away with something" or because they are lazy and do not want to do their own work (Ryan \& Carroll, 2005). The reality is that rules of academia are not the same worldwide, including ideas concerning the ownership of information, and how to acknowledge outside sources (Coates \& Dickinson, 2012).

\section{English Proficiency and Participation}

Another area where substantial difficulties and problems occur for these students has to do with expectations concerning class participation. There are reasons why some international students remain silent. For instance, a student may be good at presenting in their own language, but their imperfect English is often interpreted by faculty as "clumsy thinking," and some instructors "equate language skills and confidence styles with intelligence and the results of hard work" (Ryan \& Carroll, 2005 , p. 6). Difficulties with the English language cause problems in numerous areas including class and small group discussions and oral presentations (Coates \& Dickinson, 2012; Martirosyan et al., 2015). As Gornisiewicz and Bass (2011) noted, "Communication is the greatest barrier faced by international students and additional efforts have to be made to make them feel comfortable and to give them confidence to overcome this barrier" (p. 159).

In addition to the difficulties that many students experience communicating in English, being silent in class may be considered appropriate and respectful behavior in the student's home culture (Coates \& Dickinson, 2012; Hynes, Hill, \& Johnson, 2011). Because there are these cultural differences, international students may not understand what exactly is meant by appropriate participation behavior in terms of the host university (Zhou et al., 2005).

\section{Teaching Methods}

While lecture is still the primary method used to transfer knowledge (Chaudhury, 2011), for some international students, other instructional techniques such as roleplays, case studies, and simulations are completely unfamiliar. Research has shown that international students can find these diverse methods of learning intimidating and challenging (Gornisiewicz \& Bass, 2011). 


\section{Critical and Creative Thinking}

International students often require training in how to think critically and creatively (Coates \& Dickinson, 2012; Egege \& Kutieleh, 2004; HammersleyFletcher \& Hanley, 2016). This includes training in analyzing case studies, problem solving, asking relevant questions, and presenting original ideas confidently. Egege and Kutieleh (2004) noted that the critical thinking in Western cultures must be understood as a cultural concept and that individuals in other parts of the world think differently.

\section{Written Assignments}

In their study, Coates and Dickinson (2012) learned that many postgraduate Chinese students found it very challenging to write assignments and papers in English if they exceeded 100 words. Furthermore, many international students may also enter graduate programs without ever having written an academic research paper. Singh (2017) emphasized the importance of academic writing in master's programs as not only essential for course assignments, but also as a demonstration of critical thinking abilities.

\section{Conducting Scholarly Research and Using Academic Resources}

There are also international students who are unfamiliar with conducting scholarly research, critically evaluating source material, citing sources correctly, or structuring papers using the linear style of discourse preferred in most Western academic institutions (Burns \& Foo, 2011). In a study of a first-year experience for international undergraduates, Yan and Sendall (2016) learned that while students were told about academic resources at orientation, they were never actually trained to use those resources.

While there is a large body of research that discusses the importance of helping international students overcome these challenges (Fadil, 2010; Schulte \& Choudaha, 2014), institutions do not always provide the support necessary for success (Hynes et al., 2011; Montgomery, 2017). When international students are unable to successfully integrate into domestic academic environments, both the students and the institutions suffer (Fadil, 2010).

\section{Foundations Courses}

Strayhorn (2011) noted that research has consistently pointed to academic preparation as "an important predictor of enrollment and success in college" (p. 143), and that foundations or bridge programs have been "one of the oldest strategies used to increase student enrollment and eventual success in higher education" (p. 145). Typically, such courses take place either before the student enters their program or during the students first term or semester.

Tinto $(1975,1993)$ identified the transition phase as a key phase in student success, and he predicted that students who do not have positive interactions during the transition phase are more likely to depart without obtaining a degree. Kuh et al. 
(2007) discovered that students who participated in first-year transition programs were found to perceive the campus as being more welcoming and supportive, which further enhanced student persistence. In a study by Yan and Sendall (2016), students felt that while their first-year-program did not directly help them with their academic performance, it did help them understand the American classroom environment, how to communicate more effectively with their instructors and classmates, and it increased their self-confidence.

What is not evident in the literature, but comes through in individual university websites, is the scope and variety of foundations courses that are offered, typically through the English as a Second Language (ESL) department, that prepare international students for success. According to Andrade (2008), such programming that strengthens international students' writing and research skills build a strong platform for future success.

While most of the research on transitions programs has focused on undergraduates (Kuh et. al., 2007; Montgomery, 2017; Yan \& Sendall, 2016), transitions classes designed particularly for graduate students do exist and they are as important for graduates as they are for undergraduates (Tokuno, 2008). In Tokuno's (2008) monograph on Graduate Students in Transition, Tinto argued in the forward that no challenge is greater for graduate students than the challenge of transitioning from their former role as undergraduates to their new role as members of a scholarly community. While Tokuno's (2008) monograph contains a chapter recommending the use of first-year transition courses for domestic graduate students, research on foundations courses specifically designed for international graduate students is extremely limited (Rosenstiel et al., 2009).

International graduate students differ from undergraduates as they typically need to maintain a higher level of academic achievement than undergraduates due to the more rigorous requirements of graduate programs (i.e., passing grades for individual classes and minimum GPA requirements are typically higher than for undergraduates). As these students are typically older and more mature than undergraduates, many are already partnered and/or have dependents, which can deter them from exploring other possible relationships with domestic and other international students (Poyrazli \& Kavanaugh, 2006).

Given the previously mentioned challenges that international students may experience and the amount of information that international students need to process quickly in order to succeed in a graduate program, the rationale for a foundations course for this student population becomes even more urgent and necessary.

The following is an example of a foundations course and additional resources that provides not only an explanation of what can be done, but adds to the existing literature by providing the course components for a transition class that address the various challenges this group of students face beginning their first term.

\section{Addressing International Graduate Student Challenges in Their First Term}

The university where this example is situated is a small, private institution located in Southern California. The international graduate students are all enrolled in programs in the School of Management. These students have come from six 
continents (not including Antarctica), with the majority coming from China. They also represent a diversity of backgrounds, ages, and experiences, ranging from those with no work experience, to entrepreneurs and students who have held management positions in large international corporations. While some have undergraduate degrees in business, others have degrees in engineering, technology, and the arts.

A single, 11-week course, taken their first term, is required for international graduate students who have not already received an undergraduate (or higher) degree from a college/university in the United States. Each Foundations 500 class is limited to 16 students so that instructors can get to know the students and the specific challenges they face (e.g., difficulties with spoken or written English). In order to pass the course, a grade of $\mathrm{B}-$ or greater is required. The topics for this class were selected in part based on the challenges international students face. An overarching theme for the Foundations 500 class has to do with developing and improving academic skills. Emphasis is also placed on developing self-confidence and on oral and written communications.

Throughout the class, scaffolding, which refers to the various ways teachers adapt their instruction to support students in reaching higher levels of achievement (Shapiro et.al., 2014), is used to ensure that the material is challenging and achievable, yet not overwhelming. In this class, teams of three to four students initially work together to produce a research paper and presentation that requires students to use educational databases to source academic resources, paraphrase that information, and cite it correctly in a written document, as well as develop an oral group presentation. After they have mastered these concepts and tasks, they progress to producing an independent research paper and oral presentation. Figure 1 presents a diagram of the course outline for this class.

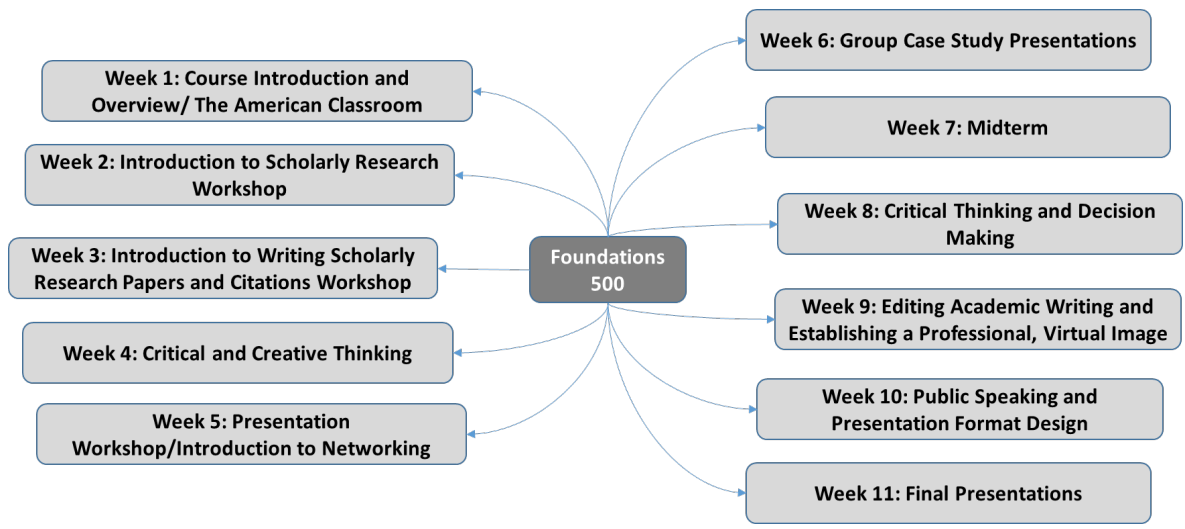

Figure 1: Course Flow for Foundations 500

\section{Additional Resources for Students' First Term}

In terms of academic and English language development, resources that are made a mandatory part of the Foundations 500 curriculum include attendance at the 
Communication Café, time spent with a writing center tutor, and writing center workshops geared for international graduate students. The Communication Café is an 8-week program that takes place in the middle of each term with games, topics, and discussions that are focused on helping nonnative English-speaking students maintain and improve their spoken English. While the Café is run almost exclusively using volunteers from the local community, occasionally domestic undergraduates will volunteer to earn points for classes they are taking. This provides both sets of students an opportunity to learn from each other-the international graduate students learn colloquial English from young adults and the undergraduates learn about the cultures of different countries.

The Foundations 500 course also uses guest speakers during the term. As the writing center plays a pivotal role in the students' academic success, an in-class introduction by representatives from that department not only provides knowledge, but helps encourage students to visit the center early in their first term. Toastmasters, an international public speaking organization, also sends a guest speaker near the end of the Foundations course. As professional networking opportunities can help students maintain and/or improve their spoken English, as well as build confidence and develop relationships with peers and members of the local business community, Foundations 500 instructors also direct students to on-campus clubs (e.g., the IT Club, United Students of the World) and other university events.

\section{How the Foundations 500 Class and Outside Resources Address International Student Challenges}

Table 1 shows how the Foundations 500 course and additional resources meet the challenges discussed in the literature.

\section{Table 1: Meeting Student Challenges}

\begin{tabular}{|l|l|l|}
\hline Challenges & Literature & $\begin{array}{l}\text { How we address these } \\
\text { challenges }\end{array}$ \\
\hline $\begin{array}{l}\text { Rules of } \\
\text { academia }\end{array}$ & $\begin{array}{l}\text { Sun et al., 2016; Yan \& } \\
\text { Sendall, 2016 }\end{array}$ & $\begin{array}{l}\text { Foundations 500 } \\
\text { (Weeks 1, 3) } \\
\text { Writing center } \\
\text { tutors/workshops }\end{array}$ \\
\hline $\begin{array}{l}\text { Intellectual } \\
\text { ownership }\end{array}$ & $\begin{array}{l}\text { Coates \& Dickinson, 2012; } \\
\text { Divan et al., 2015; Ehrich et } \\
\text { al., 2016; Ryan \& Carroll, } \\
\text { 2005 }\end{array}$ & $\begin{array}{l}\text { Foundations 500 } \\
\text { (Weeks 2, 3, 7) }\end{array}$ \\
\hline $\begin{array}{l}\text { Writing center } \\
\text { involvement/ } \\
\text { participation }\end{array}$ & $\begin{array}{l}\text { Coates \& Dickinson, 2012; } \\
\text { al., 2005 }\end{array}$ & $\begin{array}{l}\text { Foundations 500 } \\
\text { (Week 1 specifically, }\end{array}$ \\
\hline Imperfect English & $\begin{array}{l}\text { Andrade, 2008; Coates \& } \\
\text { Dickinson, 2012; }\end{array}$ & $\begin{array}{l}\text { Foundations 500 throughout the } \\
\text { term) }\end{array}$ \\
& $\begin{array}{l}\text { Feeks 1, 5, 6, 7, 9, } \\
10,11 \text { ) }\end{array}$ \\
\hline
\end{tabular}




\begin{tabular}{|c|c|c|}
\hline Challenges & Literature & $\begin{array}{l}\text { How we address these } \\
\text { challenges }\end{array}$ \\
\hline & $\begin{array}{l}\text { Martirosyan et al., 2015; } \\
\text { Ryan, 2005a }\end{array}$ & $\begin{array}{ll}\text { - } & \text { Writing center } \\
\text { - } & \text { Tutors/workshops } \\
\text { - } & \text { Toastmasters } \\
\text { - } & \text { Communication Café } \\
\text { - } & \text { Center for } \\
& \text { Entrepreneurship } \\
\text { - } & \text { Career Center } \\
\end{array}$ \\
\hline Teaching methods & $\begin{array}{l}\text { Chaudhury, 2011; Coates \& } \\
\text { Dickinson, 2012; } \\
\text { Gornisiewicz \& Bass, 2011; } \\
\text { Henderson \& Whitelaw, } \\
\text { 2013; Shapiro et al., 2014 }\end{array}$ & $\begin{array}{ll}\text { - } & \text { Foundations } 500 \\
& \text { (Weeks 1, 3, 4, 5, 6, 8) } \\
\text { - } & \text { Communication Café }\end{array}$ \\
\hline $\begin{array}{l}\text { Critical and } \\
\text { creative thinking }\end{array}$ & $\begin{array}{l}\text { Coates \& Dickinson, 2012; } \\
\text { Eege \& Kutieleh, 2004; } \\
\text { Hammersley-Fletcher \& } \\
\text { Hanley, } 2016\end{array}$ & $\begin{array}{ll}\text { - } & \text { Foundations } 500 \\
& (\text { Week 4, 8) } \\
\text { - } & \text { Communication Café }\end{array}$ \\
\hline $\begin{array}{l}\text { Scholarly } \\
\text { research and } \\
\text { writing }\end{array}$ & $\begin{array}{l}\text { Burns \& Foo, 2011; Coates } \\
\& \text { Dickinson, 2012; Divan et } \\
\text { al., } 2015\end{array}$ & $\begin{array}{ll}\text { - } & \text { Foundations } 500 \\
& \text { (Weeks 2,9) } \\
\text { - } & \text { Research librarian } \\
\text { - } & \text { Writing center } \\
& \text { tutors/workshops } \\
\end{array}$ \\
\hline
\end{tabular}

\section{CONCLUSION}

A foundations course can provide opportunities for international graduate students to become acclimated to the requirements for success in the host academic culture before they move into higher level classes, allowing them to be on a more even footing with domestic students. Exposure to the concepts of intellectual ownership, academic dishonesty, and instruction in properly citing outside sources can result in fewer instances of plagiarism and cheating. Practicing their presentation skills prepares students to demonstrate professionalism and gain confidence. By exposing students to a range of techniques such as case studies and role-plays, students are able to continue honing critical and creative thinking skills. Such a course allows students to break out of their comfort zone in a safe environment. For these students, practice and repetition are the hallmark of mastery.

Institutions should consider building collaborative ties with both internal and external services and resources that can provide support for this student population (e.g., writing center workshops, auditing classes at a local English Language School, Toastmasters). In addition, gathering information from international students themselves as they complete their first graduate term and again midprogram can reveal topics important to this student group. 
While the development of a foundations course along with additional resources can help rectify many of the challenges international students face, relying on past research that deals primarily with domestic or even international undergraduate transitions programs does not address problems that international students moving on to graduate studies may face such as developing a stronger sense of purpose and professional goals, as well as navigating the growing complexities and priorities of adulthood (Poyrazli \& Kavanaugh, 2006; Tokuno, 2008). Future empirical research focusing specifically on international graduate students is needed so that better support can be provided to meet the needs of those pursuing a graduate degree. Other examples of graduate-level foundation courses for international students are needed so that practitioners can compare and contrast subject offerings in order to develop appropriate materials for their own unique populations. In addition, studies that investigate entry level programs and resources with continued persistence and completion would be beneficial so that institutions can provide the most appropriate guidance and support.

\section{REFERENCES}

Andrade, M. S. (2008). International graduate students: Adjusting to study in the United States. In K. A. Tokuno (Ed.), Graduate students in transition: Assisting students through the first year (Monograph No. 50, 71-90). University of South Carolina, National Resource Center for the First-Year Experience and Students in Transition.

Burns, C., \& Foo, M. (2011). International students' perceptions of their global skills development: A collaborative approach. Emerge, 2010(3), 25-42.

Chaudhury, S. R. (2011). The lecture. New Directions for Teaching and Learning, $128,13-20$.

Coates, N., \& Dickinson, J. (2012). Meeting international postgraduate student needs: A programme based model for learning and teaching support. Innovations in Education and Teaching International, 49(3), 295-308. doi:10.1080/14703297.2012.703018

Divan, A., Bowman, M., \& Seabourne, A. (2015). Reducing unintentional plagiarism amongst international students in the biological sciences: An embedded academic writing development programme. Journal of Further and Higher Education, 39(3), 358-378.

Egege, S., \& Kutieleh, S. (2004). Critical thinking: Teaching foreign notions to foreign students. International Education Journal, 4(4), 75-83.

Ehrich, J., Howard, S. J., Congjun, M., \& Bokosmaty, S. (2016). A comparison of Chinese and Australian university students' attitudes towards plagiarism. Studies in Higher Education, 41(2), 231-246.

Fadil, P. A. (2010). Determining the effect of international student assimilation. Journal of International Business Disciplines, 4(2), 50-67.

Gornisiewicz, W., \& Bass, O. (2011). Supporting international students to meet assessment expectations. Australasian Journal of Engineering Education, 17(3), $157-162$. 
Hammersley-Fletcher, L., \& Hanley, C. (2016). The use of critical thinking in higher education in relation to the international student: Shifting policy and practice. British Educational Research Journal, 42(6), 978-992. doi:10.1002/berj.3246

Henderson, F., \& Whitelaw, P. A. (2013). Academic literacy and cultural familiarity: Developing and assessing academic literacy resources for Chinese students. Interdisciplinary Journal of E-Learning and Learning Objects, 9, 13-27.

Hynes, G. E., Hill, K. L., \& Johnson, B. (2011). International students' unfamiliarity with U.S. business culture: Overcoming a roadblock to success in MBA programs. Journal for Global Business Education, 11, 17-29.

Korobova, N., \& Starobin, S. (2015). A comparative study of student engagement, satisfaction, and academic success among international and American students. Journal of International Students, 5(1), 72-85.

Kuh, G. D., Kinzie, J., Buckley, J., Bridges, B., \& Hayek, J. C. (2007). Piecing together the student success puzzle: Research, propositions, and recommendations. ASHE Higher Education Report, 32(5). Jossey-Bass.

Martirosyan, N., Hwang, E., \& Wanjohi, R. (2015). Impact of English proficiency on academic performance of international students. Journal of International Students, 5(1), 60-71.

Montgomery, K. A. (2017). Supporting Chinese undergraduate students in transition at U.S. colleges and universities. Journal of International Students, 7(4), 963 989.

Poyrazli, S., \& Kavanaugh, P. R. (2006). Marital status, ethnicity, academic achievement, and adjustment strains: The case of graduate international students. College Student Journal, 40(4), 767-780.

Rosenstiel, E. D., Taaffe, J., \& Thomas, L. J. (2009). The graduate preparation program at the Ohio State University. In M. S. Andrade \& N. W. Evans (Eds.), International students: Strengthening a critical resource. (pp. 147-151). Rowman \& Littlefield.

Ryan, J. (2005a). Improving teaching and learning practices for international students: Implications for curriculum, pedagogy and assessment. In J. Carroll \& J. Ryan (Eds.), Teaching international students: Improving learning for all (pp. 92-100). Routledge.

Ryan, J. (2005b). The student experience: Challenges and rewards. In J. Carroll \& J. Ryan (Eds.), Teaching international students: Improving learning for all. (pp. 147-151). Routledge.

Ryan, J., \& Carroll, J. (2005). "Canaries in the coalmine": International students in Western universities. In J. Carroll \& J. Ryan (Eds.), Teaching international students: Improving learning for all (pp. 3-10). Routledge.

Ryan, J., \& Hellmundt, S. (2005). Maximizing international students' 'cultural capital.' In J. Carroll \& J. Ryan (Eds.), Teaching international students: Improving learning for all (pp. 13-16). Routledge.

Sawir, E. (2013). Internationalisation of higher education curriculum: The contribution of international students. Globalisation, Societies and Education, 11(3), 359-378, doi:10.1080/14767724.2012.750477

Schulte, S., \& Choudaha, R. (2014). Improving the experiences of international students. Change: The Magazine of Higher Learning, 46(6), 52-58. 
Shapiro, S., Farrelly, R., \& Zuzana, T. (2014). Fostering international student success in higher education. TESOL Press.

Singh, M. K. M. (2017). International EFL/ESL master students' adaptation strategies for academic writing practices at tertiary level. Journal of International Students, $7(3), 620-643$.

Strayhorn, T. L. (2011). Bridging the pipeline: Increasing underrepresented students' preparation for college through a summer bridge program. American Behavioral Scientist, 55(2), 142-159.

Sun, T., Otoum, M., \& Stetar, B. (2016). Global discovery of learning motivations: Systemic enhancements within higher education. Transnational Journal of Business, 1(1), 8-20.

Tinto, V. (1975). Dropout from higher education: A theoretical synthesis of recent research. Review of Educational Research, 45, 89-125.

Tinto, V. (1993). Leaving college: Rethinking the causes and cures of student attrition. University of Chicago Press.

Tokuno, K. A. (2008). Theories relating to the transition into graduate study. In K. A. Tokuno (Ed.), Graduate students in transition: Assisting students through the first year (Monograph No. 50, p 47-56). University of South Carolina. National Resource Center for the First Year Experience and Students in Transition.

Wu, H., Garza, E., \& Guzman, N. (2015). International student's challenge and adjustment to college. Education Research International, 2015, Article 202753.

Yan, Z., \& Sendall, P. (2016). First year experience: How we can better assist firstyear international students in higher education. Journal of International Students, $6(1), 35-51$.

Zhou, Y. R., Knoke, D., \& Sakamato, I. (2005). Rethinking silence in the classroom: Chinese students' experiences of sharing indigenous knowledge. International Journal of Inclusive Education, 9(3), 287-311.

MARY JO SHANE, PhD, has worked in the field of human and organization development and effectiveness since 1991 with both profit-generating organizations, as well as nonprofit foundations. Her areas of specialization as a consultant include diversity, culture, and change management. At California Lutheran University, she is an Assistant Professor and the Director of International Student Success for the School of Management where her responsibilities include the planning and implementation of programs, events and special projects for international students. Email: mjshane@callutheran.edu

LOREDANA CARSON, EdD, has a BA in linguistics from UCLA, a TESOL Certificate from UCSB, and a Master's in Public Policy and Public Administration from California Lutheran University. She received her EdD degree in 2020. Her research interests include international student cultural and academic engagement as well as language and education policy. She currently serves as a lecturer for the School of Management at California Lutheran University in Thousand Oaks, California. Email: carson@callutheran.edu 
GLORIA MACRI, PhD, received her doctorate in Communication Studies from Dublin City University and has an undergraduate degree and master's in sociology. For over 10 years, she has taught many courses ranging from core, introductory courses to courses that apply theories and complex concepts such as culture, race, and ethnicity to explore communities and various social issues and processes in a wide range of social contexts. For the past 2 years she has taught the incoming international graduate students in the School of Management at California Lutheran University. Her research interests include education, non-profit organizations, cultural identity formation and cross-cultural communication, and online communities. Email: dmacri@callutheran.edu 